doi: $10.15407 /$ ukrbotj74.03.212

\title{
Erysiphe salmonii (Erysiphales, Ascomycota), another East Asian powdery mildew fungus introduced to Ukraine
}

\author{
Vasyl P. HELUTA ${ }^{1}$, Susumu TAKAMATSU ${ }^{2}$, Siska A.S. SIAHAAN ${ }^{2}$ \\ ${ }^{1}$ M.G. Kholodny Institute of Botany, National Academy of Sciences of Ukraine \\ 2 Tereshchenkivska Str., Kyiv 01004, Ukraine \\ vheluta@botany.kiev.ua \\ ${ }^{2}$ Department of Bioresources, Graduate School, Mie University \\ 1577 Kurima-Machiya, Tsu 514-8507, Japan \\ takamatu@bio.mie-u.ac.jp
}

Heluta V.P., Takamatsu S., Siahaan S.A.S. Erysiphe salmonii (Erysiphales, Ascomycota), another East Asian powdery mildew fungus introduced to Ukraine. Ukr. Bot. J., 2017, 74(3): 212-219.

Abstract. In 2015, a powdery mildew caused by a fungus belonging to Erysiphe sect. Uncinula was recorded on two species of ash, Fraxinus excelsior and F. pennsylvanica (Oleaceae), from Ukraine (Kyiv, two localities). Based on the comparative morphological analysis of Ukrainian specimens with samples of Erysiphe fraxinicola and E. salmonii collected in Japan and the Far East of Russia, the fungus was identified as E. salmonii. This identification was confirmed using molecular phylogenetic analysis. This is the first report of E. salmonii not only in Ukraine but also in Europe. It is suggested that the records of E. fraxinicola from Belarus and Russia could have been misidentified and should be corrected to E. salmonii. In 2016, the fungus was found not only in Kyiv but also outside the city. The development of the fungus had symptoms of a potential epiphytotic disease. Thus, it may become invasive in Ukraine and spread to Western Europe in the near future.

Keywords: molecular phylogeny, Uncinula, ornamental planting, Fraxinus, ash, Europe

\section{Introduction}

Species of ash (Fraxinus L.) are quite decorative and grown as ornamental plants in parks, botanical gardens and green spaces. For example, twenty species of this genus are cultivated in Ukraine (Kokhno, 1986), of which eight species are native to Ukraine (Mosyakin, Fedoronchuk, 1999). Of these, F. excelsior L. is the most common species in natural forests and artificial plantations of Ukraine. Some Fraxinus species are hosts of powdery mildews. Phyllactinia fraxini (DC.) Fuss was reported here on $F$. americana L., F. excelsior, F. ornus L., F. oxycarpa Willd., and F. sogdiana Bunge (Heluta et al., 1987; Heluta, 1989; Andrianova et al., 2006). This fungus is a semi-endophytic parasite, since it forms both endophytic and superficial mycelia. Fruit bodies and conidial sporulation of the fungus are confined to lower surfaces of leaves. Thus, whilst the fungus does not cause significant damage to host plants and does not immediately reduce their ornamental value, it does lead to premature defoliation. Until now,

(C) V.P. HELUTA, S. TAKAMATSU, S.A.S. SIAHAAN , 2017 only this powdery mildew was recorded on Fraxinus species in Ukraine, while outside the country other powdery mildews of ash have been described by Braun and Cook (2012), e.g.: Erysiphe fraxinicola U. Braun \& S. Takam. and E. salmonii (Syd.) U. Braun \& S. Takam. from sect. Uncinula (Lév.) U. Braun \& Shishkoff; E. syringae Schwein. from sect. Microsphaera (Lév.) U. Braun \& Shishkoff and P. fraxinicola U. Braun \& H.D. Shin. Most Erysiphe species produce clearly visible amphigenous mycelia (Fig. 1,a). Until the beginning of the $21^{\text {st }}$ century, these species parasitizing ash were not known in Europe. However, in the first decade of this century E. fraxinicola (as Uncinula fraxini Miyabe) on $F$. excelsior was reported in Belarus (Galynskaya, Garanovich, 2009), later on a Fraxinus sp. in Russia (Moscow, Central Botanical Garden) (Mukhina et al., 2015). In 2015, a powdery mildew belonging to Erysiphe sect. Uncinula was found on ash in Kyiv (Fig. 1, $a-e$ ) by the first author of this article. Our aim here was to identify more precisely this fungus, which is new to Ukraine. 


\section{Materials and methods}

\section{Molecular phylogenetic analysis}

The nucleotide sequences of the 5'-end of the nuc $28 \mathrm{~S}$ rDNA (including domains D1 and D2) and the nuc rDNA ITS1-5.8S-ITS2 (ITS) were determined by the procedure described by Takamatsu et al. (2013). The sequences determined in this study were deposited in DNA Data Base of Japan (DDBJ) under the accession numbers LC259500-LC259502. They were aligned with other sequences of the genus Erysiphe retrieved from DNA databases using MUSCLE (Edgar, 2004) implemented in MEGA 6 (Tamura et al., 2013). The alignment was further manually refined using the MEGA6 program and deposited in TreeBASE (http:// www.treebase.org/) under the accession number S20912. Phylogenetic trees were obtained from the data with maximum parsimony (MP) and maximum likelihood (ML) analyses. MP analyses were conducted by PAUP 4.0a152 (Swofford, 2002) with the heuristic search option using 'tree bisection-reconstruction' (TBR) algorithm with 100 random sequence additions to find the global optimum tree. All sites were treated as unordered and unweighted, with gaps treated as missing data. Tree scores, including tree length, consistency index (CI), retention index (RI), and rescaled consistency index (RC) were also calculated. The strength of internal branches of the resulting trees was tested with bootstrap (BS) analysis (Felsenstein, 1985) using 1000 replications with the step-wise addition option set as simple. The ML analysis was done with raxmlGUI (Silvestro, Michalak, 2012) under a GTRGAMMA model. The BS supports and trees were obtained by running rapid bootstrap analysis of 1000 pseudo replicates followed by a query for the tree with the highest likelihood. BS supports of $70 \%$ or higher are shown.

\section{Morphological study}

Leaves of Fraxinus spp. with powdery mildew symptoms were collected from $F$. excelsior and $F$. pennsylvanica in Ukraine, from $F$. rhynchophylla in the Far East of Russia and from $F$. longicuspis in Japan. They were dried between paper at $22-24^{\circ} \mathrm{C}$ and deposited in the National Herbarium of the M.G. Kholodny Institute of Botany of the National Academy of Sciences of Ukraine $(K W-M)$ and partly in Mie University Mycological Herbarium (TSU-MUMH). The detailed sample list is shown after the species description. The mycelium, conidiophores and conidia were removed from the surface of infected leaves by transparent adhesive tape, observed and photographed in a drop of distilled water under a light microscope "Primo Star" (Carl Zeiss, Germany) with the camera "Canon A 300" and the software "AxioVision 4.7". To restore shape and size of dried appendages, chasmothecia were put in a droplet of $40 \%$ lactic acid solution on a microscope slide, covered with a cover glass, gently heated to boiling point, and then examined under the light microscope.

\section{Results}

\section{Morphological study}

A careful examination of all Erysiphe specimens collected in Ukraine on Fraxinus spp. showed that both asexual and sexual morphs were uniform and clearly belonged to the same species. They were compared with the descriptions of E. fraxinicola and E. salmonii given in the monograph by Braun and Cook (2012), and with specimens collected in Japan and the Far East of Russia. The asexual morphs of the Ukrainian material were very similar to those of $E$. salmonii and clearly distinct from those reported for E. fraxinicola. They had much shorter conidiophores (50-66 $\mu \mathrm{m}$ long compared to up to $120 \mu \mathrm{m}$ for E. fraxinicola). As shown in the table below, the quantitative characteristics of the sexual morphs mostly overlapped. However, chasmothecia of Ukranian origin had appendages gradually increasing in width towards the tip, with uncinate to tightly circinate apices (Fig. 1, f), whereas E. fraxinicola had mostly longer appendages of the same width throughout (Fig. 1, $h$ ) and a larger number of spores in the ascus. Based on both the asexual and sexual characters, Ukrainian material fitted much better with $E$. salmonii, than with $E$. fraxinicola. This conclusion was consistent with the results of the phylogenetic analysis given below. Detailed morphological characteristics of the fungus are also provided in the taxonomic description below.

\section{Molecular phylogenetic analysis}

We used a combined data set of ITS and 28S rDNA sequences to investigate phylogenetic relationships of the eight sequences from Fraxinus powdery mildews. The ITS + 28S rDNA combined data set consisted of 9 sequences and 1417 characters, of which 191 (13.5\%) characters were variable and $33(0.3 \%)$ were informative for parsimony analysis. A total of three equally parsimonious trees with 209 steps were constructed by the MP analysis. Tree topologies were almost consistent among the trees, except for branching orders of the terminal branches. One of the trees with the highest likelihood value is shown in Fig. 2. ML analysis 

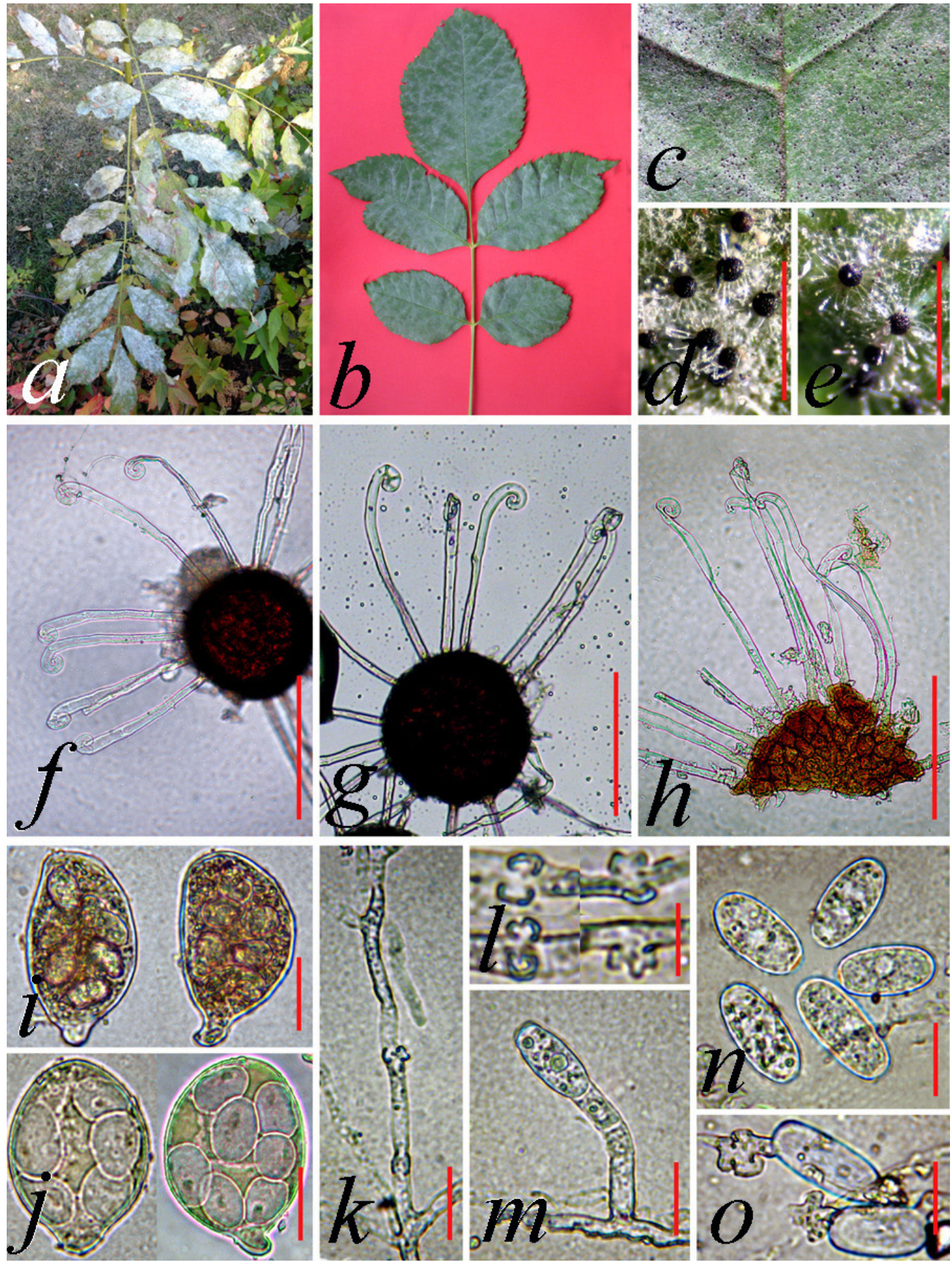

Fig. 1. Erysiphe salmonii on Fraxinus spp. $(a-g, i-o)$; on Fraxinus excelsior $(a, d-f, i-j), F$. pennsylvanica $(b, c, k-o)$, F. rhynchophylla $(g)$ and $\boldsymbol{E}$. fraxinicola on $F$. longicuspis $(h): a, b$ - superficial mycelia on leaves; $c$ - chasmothecia on upper surface of leaf; $d, e$ - chasmothecia as viewed in reflected light and $f-h$ - by light microscopy; $f, g$ - showing appendages of Erysiphe salmonii (for comparison with $h-E$. fraxinicola); $i, j-$ asci with ascospores ( $j$ - pressed hard by the cover slip); $k$ - hypha; $l$ - hyphal appressoria; $m$ - living conidiophore; $n, o$ - living conidia (o- with conidial appressoria) (bars: $d, e-$ $500 \mu \mathrm{m}, f-h-100 \mu \mathrm{m}, i-k, j, m-20 \mu \mathrm{m}, l-10 \mu \mathrm{m})$ 
Comparisons of morphological characteristics of Erysiphe salmonii and E. fraxinicola collected on species of the genus Fraxinus in Ukraine and beyond

\begin{tabular}{|c|c|c|c|c|c|}
\hline \multirow[b]{2}{*}{ Feature } & \multicolumn{3}{|c|}{ Erysiphe salmonii } & \multicolumn{2}{|c|}{ Erysiphe fraxinicola } \\
\hline & $\begin{array}{c}\text { Fraxinus excelsior, } \\
\text { Ukraine, } K W-M 70587 \\
(M U M H 6789)\end{array}$ & $\begin{array}{c}\text { Fraxinus rhynchophylla, } \\
\text { far East of Russia, } K W-M \\
70591 \text { (MUMH 6790) }\end{array}$ & $\begin{array}{l}\text { Fraxinus spp. } \\
\text { (Braun, Cook, } \\
\text { 2012) }\end{array}$ & $\begin{array}{c}\text { Fraxinus } \\
\text { longicuspis, Japan, } \\
\text { MUMH } 211\end{array}$ & $\begin{array}{c}\text { Fraxinus spp. (Braun, } \\
\text { Cook, 2012) }\end{array}$ \\
\hline Conidiophore length, $\mu \mathrm{m}$ & $50-66$ & - & $45-70$ & - & Up to 120 \\
\hline Conidium length, $\mu \mathrm{m}$ & $26-35$ & - & $22-30$ & - & $22-45$ \\
\hline Conidium width, $\mu \mathrm{m}$ & $12.5-13.5$ & - & $11-15$ & - & $11-18$ \\
\hline Chasmothecial diam, $\mu \mathrm{m}$ & $84-133(-138)$ & $86-116$ & $70-140$ & $82-110$ & $70-130$ \\
\hline Number of appendages & $15-26(-33)$ & $12-17(-21)$ & $4-32$ & $13-20$ & $8-40$ \\
\hline $\begin{array}{l}\text { Appendage length, as proportion } \\
\text { of chasmothecial diam. }\end{array}$ & $1.1-1.5$ & $0.9-2.0$ & $1-2$ & $1-2$ & $1.5-2.5$ \\
\hline Number of asci & $4-9$ & $3-5$ & $3-9$ & & $4-10$ \\
\hline Ascus length, $\mu \mathrm{m}$ & $38-51$ & $40-49$ & $40-70$ & $42-56$ & $40-70$ \\
\hline Ascus width, $\mu \mathrm{m}$ & $24-39$ & $31-46$ & $30-50$ & $35-50$ & $25-55$ \\
\hline Ascus, length/width ratio & $1.1-1.9$ & $1.0-1.5$ & - & $1.0-1.4$ & - \\
\hline Number of spores & $(5-) 6-7$ & $7-8$ & $(4-) 6-8$ & $(7-) 8$ & $6-8$ \\
\hline Spore length, $\mu \mathrm{m}$ & $12-22.5$ & $16-21$ & $12.5-22$ & $13.5-21$ & $12.5-25$ \\
\hline Spore width, $\mu \mathrm{m}$ & $9-13$ & $9-12.5$ & $7-14$ & $10.5-14$ & $7-13$ \\
\hline Spore, length/width ratio & $1.1-2.0$ & $1.5-2.0$ & - & $1.1-1.7$ & - \\
\hline
\end{tabular}

\section{Erysiphe salmonii}

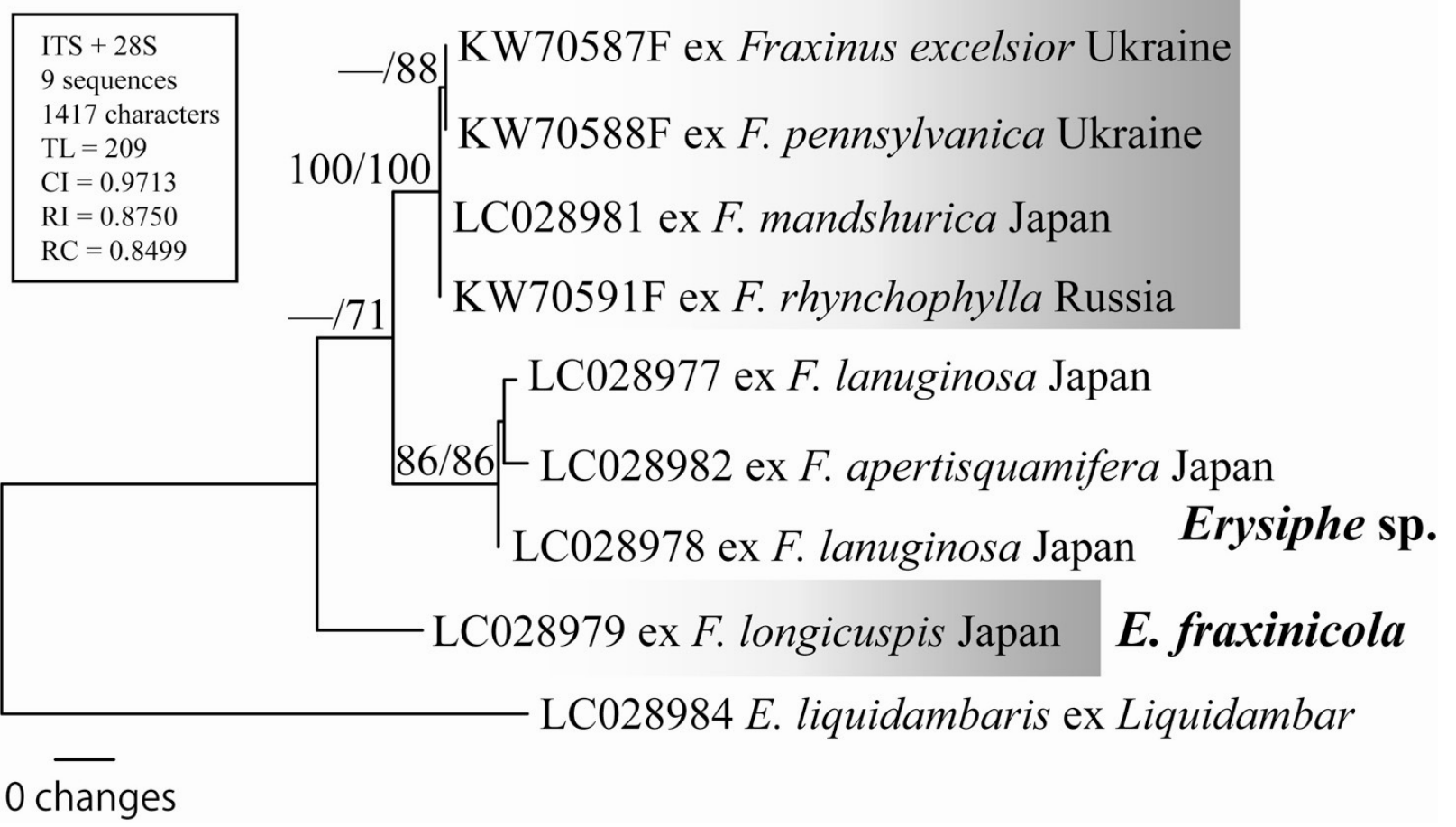

Fig. 2. Phylogenetic analysis of rDNA ITS region and 28S rDNA (including D1/D2 domains) for eight sequences from Fraxinus powdery mildews. This tree is one of the three equally parsimonious trees with 209 steps, which were found using a heuristic search. Horizontal branch lengths are proportional to the number of substitutions that were inferred to have occurred along a particular branch of the tree. BS ( $\geq 70 \%$ ) values by the maximum parsimony (MP) and maximum likelihood (ML) methods were shown on the respective branches 
generated a tree topology almost identical to the MP tree, and only BS support values are shown on the MP tree. The eight sequences from Fraxinus powdery mildews were divided into three distinct groups. The three sequences from Ukrainian and Russian samples formed a clade with a sequence (LC028981) from a Japanese sample with strong BS supports (100\% in both MP and ML). This Japanese sample was identified as E. salmonii. Thus, both morphological and molecular analyses show that the powdery mildew fungus recorded on ash in Ukraine belongs to E. salmonii.

Erysiphe salmonii (Syd. \& P. Syd.) U. Braun \& S. Takam., Schlechtendalia 4: 23. 2000 (Fig. 1, $a-g$, $i-o$ )

Syn. Uncinula salmonii Syd. \& P. Syd. [as 'salmoni'], Annls mycol. 11(2): 114. 1913.

Mycelium amphigenous, in white indistinct patches of varying size merging into a continuous coating or greyish, effuse on the upper side of the leaf surface, inconspicuous on the underside of the leaf. Superficial hyphae more or less straight or slightly twisted, 2.8-5.2 $\mu \mathrm{m}$ wide. Hyphal appressoria mainly in opposite pairs, entire or moderately lobed, $4.5-8 \mu \mathrm{m}$ diam. Conidiophores 50-66 $\mu \mathrm{m}$ long, consisting of a cylindrical, relatively short $(15-31 \mu \mathrm{m})$ foot cell, usually followed by a single shorter cell and an young conidium. Conidia formed singly, ellipsoidal-oblong to subcylindrical, $26-35 \times 12.5-13.5 \mu \mathrm{m}$, with a length/breadth ratio of $1.5-2.4$, germinating with one or two short terminal germ tubes, conidial appressoria multilobate. Chasmothecia scattered to more or less gregarious, 84-133(-138) $\mu \mathrm{m}$ diam. Peridium cells irregularly polygonal, $8-18 \mu \mathrm{m}$ diam. Appendages $15-$ 26(-33), equatorial, relatively stiff or some arcuate and geniculate, $1.1-1.5$ times as long as the chasmothecial diam (up to $137 \mu \mathrm{m}$ long), width $5.8-7 \mu \mathrm{m}$ below, increasing to about $7.5-9 \mu \mathrm{m}$ towards the tip or width fairly often more of less equal throughout, without or occasionally with a single basal septum, basal half rough-walled, apices uncinate to tightly circinate. Asci 4-9, ellipsoid-ovoid or ellipsoid-obovoid, 38-51 $\times 24-$ $39 \mu \mathrm{m}$, stalked, (5-)6-7-spored. Ascospores ovoid or ellipsoidal, $12-22.5 \times 9-13 \mu \mathrm{m}$, hyaline.

\section{Specimens examined}

\section{Erysiphe fraxinicola}

On Fraxinus longicuspis Siebold \& Zukk.: Japan: Niigata Pref., Yahiko-mura, Mt. Yahiko, 18.10.1996, S. Takamatsu (TSU-MUMH 211).

\section{Erysiphe salmonii}

On Fraxinus excelsior L.: Ukraine: Kyiv, Centre, Bohdan Khmelnytskyi Str., 16.10.2015, V. Heluta $(K W-M$ 70587; TSU-MUMH 6789).

On Fraxinus mandshurica Rupr.: Japan: Hokkaido, Sapporo-shi, Hokkaido University, Botanical Garden, 02.09.1995, Yukio Sato (TSU-MUMH s96).

On Fraxinus pennsylvanica Marshall: Ukraine: Kyiv, Novobilychi, Bulakhovskyi Str., 15.10.2016, V.P. Hayova ( $K W-M$ 70837); Solomyanka, Vasyl Lypkivskyi Str., Oct 2016, S.L. Mosyakin ( $K W$ $M$ 70838); Pivdenna Borshchahivka, Academician Koroliov Ave., 19.10.2015, V. Heluta ( $K W-M$ 70588; TSU-MUMH 6792), 15.09.2016, V. Heluta ( $K W$ $M$ 70840), 25.09.2016, V. Heluta ( $K W-M$ 70841), 10.10.2016, V. Heluta ( $K W-M$ 70842); Pivdenna Borshchahivka, 9 Bulgakov Str., 04.10.2016, V. Heluta ( $K W-M$ 70843); Pivdenna Borshchahivka, 17 Symyrenko Str., 19.10.2016, V. Heluta ( $K W-M 70844)$; Kyiv Region: Kotsyubynske urban village, near the railway station Bilychi, 04.09.2016, V. Heluta $(K W-M$ 70845), 14.10.2016, V. Heluta ( $K W-M$ 70846); near Kotsyubinske urban village, 04.09.2016, V. Heluta ( $K W-M$ 70848), 30.09.2016, T. Krupodiorova $(K W-M$ 70849).

On Fraxinus rhynchophylla Hance: Russian Federation, Primorsky Krai (Far East of Russia), Vladivostok, 18.09.1989, V.P. Heluta ( $K W-M$ 70591; TSU-MUMH 6790).

\section{Discussion}

Many years ago, one of the authors of this paper proposed a hypothesis about the origin and migration of powdery mildew fungi (Heluta, 1992; Voytyuk et al., 2009). According to the hypothesis, the center of origin of these fungi is located in East Asia. From there powdery mildew fungi migrated into the European part of the Eurasian continent. This process seems to continue up until now, as evidenced by new records of East Asian powdery mildew species in Europe. For example, the following powdery mildew species have been found in Ukraine within the last few decades: Erysiphe palczewskii (Jacz.) U. Braun \& S. Takam. (Heluta, 1981; Heluta, Gorlenko, 1984; Braun, 1985; Romaszewska-Sałata et al., 1986; Shukanov, Stefanovich, 1986; Scholler, 1994; Spooner, Roberts, 2001; Lebeda et al., 2008), E. vanbruntiana (W.R. Gerard) U. Braun \& S. Takam. (Heluta, 1981; Heluta \& Gorlenko, 1981; Romaszewska-Sałata et al., 1986; Shukanov, Stefanovich, 1986; Fakirova, 1993), E. syringae-japonicae (U. Braun) U. Braun 
\& S. Takam. (Seko et al., 2008, 2011), E. arcuata U. Braun, V.P. Heluta \& S. Takam. (Braun et al., 2006; Pastirčáková, 2008), E. kenjiana (Homma) U. Braun \& S. Takam. (Heluta et al., 2009), E. macleayae R.Y. Zheng \& G.Q. Chen (Dynowska et al., 1999; Jankovics, 2007; Heluta, Kravchuk, 2015; Heluta et al., 2016), and Neoerysiphe geranii (Y. Nomura) U. Braun (Heluta, 2001; Heluta et al., 2010). Erysiphe salmonii recently found in Ukraine is probably the result of this migration process as well.

Until recently, E. salmonii was known only from China and Japan, where it was found on host plants belonging to the genera Fraxinus L. and Syringa L. (Chen et al., 1987; Braun, Cook, 2012). However, the same species was also recorded by one of the authors of this paper in the Far East of the Russian Federation in September 1989 (unpublished data). Obviously, some of the specimens collected there by Bunkina (1991) also belong to this species, and not to E. fraxinicola mentioned by the author as Uncinula fraxini. It is possible that ' $U$. fraxini' from South Korea also belongs to E. salmonii, as the appendages of Korean specimens depicted by Shin (Shin, 2000, fig. 94F) are increasing towards the tip. Unfortunately, reports on the findings of E. fraxinicola in Belarus and the European part of Russia were not accompanied by morphological descriptions. Thus it is possible that they actually belonged to $E$. salmonii taking into account the finding of this species in Ukraine. Either way, we can say that at least one more East Asian species of powdery mildew fungi has been introduced into Europe.

Note that E. salmonii was found only in two localities in Kyiv in 2015, viz. in the center of the city and on a residential area Pivdenna (South) Borshchahivka, but no mature plants, only 2-3-year-old ash seedlings, were infected at this time. However, next year E. salmonii was recorded in the central part of the city (but in different localities) and elsewhere in South Borshchahivka and on the outskirts of Kyiv. Although only young plants were infected, the monitoring of the development of E. salmonii in and around Kyiv demonstrated the significant invasive potential of this ash parasite. Therefore, it is highly likely that the fungus will soon reach Western Europe.

\section{Acknowledgments}

Authors are grateful to Dr. Vera Hayova, Dr. Tetyana Krupodiorova, and Prof. Sergei Mosyakin for kindly providing specimens of ash leaves infected with powdery mildew. We also thank Dr. Roger Cook for his help with
English and valuable comments on the manuscript. This work was financially supported in part by a Grant-in-Aid for Scientific Research (No. 16 K07613 and 16F16097) from the Japan Society for the Promotion of Science, Japan to ST, and the Hashiya Scholarship Foundation awarded to SASS.

\section{REFERENCES}

Andrianova T.V., Dudka I.O., Hayova V.P., Heluta V.P., Isikov V.P., Kondratiuk S.Ya., Krivomaz T.I., Kuzub V.V., Minter D.W., Minter T.J., Prydiuk M.P., Tykhonenko Yu.Ya. Fungi of Ukraine, 2006, available at: www. cybertruffle.org.uk/ukrafung/eng [website, version 1.00].

Braun U. Taxonomic notes on some powdery mildews $(\mathrm{V})$. Mycotaxon, 1985, 32: 87-96.

Braun U., Cook R.T.A. Taxonomic manual of the Erysiphales (powdery mildews). CBS Biodiv., Ser. 11, 2012: 1-707.

Braun U., Takamatsu S., Heluta V., Limkaisang S., Divarangkoon R., Cook R., Boyle H. Phylogeny and taxonomy of powdery mildew fungi of Erysiphe sect. Uncinula on Carpinus species. Mycol. Progr., 2006, 5(3): 139-153.

Bunkina I.A. Poryadok Erysiphales. In: Nizshie rasteniya, griby i mokhoobraznye sovetskogo Dalnego Vostoka. Griby. Tom 2. Askomitsety. Eryzifalnye, klavitsipitalnye, gelotsialnye. Ed. Z.M. Azbukina, Leningrad: Nauka, 1991, pp. 11-142. [Бункина И.А. Порядок Erysiphales. В кн.: Низшие растения, грибы и мохообразные советского Дальнего Востока. Грибы. Т. 2. Аскомицеты. Эризифальные, клавиципитальные, гелоциальные. Ред. 3.М. Азбукина, Л.: Наука, 1991, с. 11-142].

Chen G.-Q., Han S.-J., Lai Y.-Q., Yu Y.-N., Zheng R.-Y. Flora Fungorum Sinicorum. Erysiphales, China: Science Press, 1987, vol. 1, 552 pp.

Dynowska M., Fiedorowicz G., Kubiak D. Contributions to the distribution of Erysiphales in Poland. Acta Mycol., 1999, 34: 79-88.

Edgar R.C. MUSCLE: multiple sequence alignment with high accuracy and high throughput. Nucleic Acids Res., 2004, 32: 1792-1797.

Fakirova V.I. Distribution of Microsphaera vanbruntiana Ger. var. sambuci-racemosae U. Braun and Erysiphe magnicellulata U. Braun (Fam. Erysiphaceae) in Bulgaria. Fitol., 1993, 44: 32-34.

Felsenstein J. Confidence limits on phylogenetics: an approach using the bootstrap. Evolution, 1985, 39: 783-791.

Galynskaya N.A., Garanovich I.M. Visn. Ukrain. t-va henetykiv $i$ selektsioneriv, 2009, 7(1): 17-30. [Галынская Н.А., Гаранович И.М. Фитопатологическая оценка древесных растений и видовой состав патогенов в старинных парках Витебской области. Вiсн. Укр. m-ва генетиків і селекціонерів, 2009, 7(1): 17-30].

Heluta V.P. Ukr. Bot. J., 1981, 38(6): 50-52. [Гелюта В.П. Нові для мікофлори УРСР види роду Microsphaera Lev. Укр. бот. жкурн., 1981, 38(6): 50-52].

Heluta V.P. Flora grybov Ukrainy. Muchnistorosyanye griby, Kiev: Naukova Dumka, 1989, 256 рр. [Гелюта В.П. Флора грибов Украины. Мучнисторосяные грибы, Киев: Наук. думка, 1989, 256 с.]. 
Heluta V.P. Ukr. Bot. J., 1992, 49(5): 5-14. [Гелюта В.П. Гіпотеза про походження та міграції грибів порядку Erysiphales. Укр. бот. жмурн., 1992, 49(5): 5-14].

Heluta V.P. Ukr. Bot. J., 2001, 58(2): 239-242. [Гелюта В.П. Neoerysiphe geranii (Y. Nomura) U. Braun - новий для України вид борошнисторосяного гриба. Укр. бот. журн., 2001, 58(2): 239-242].

Heluta V.P., Gorlenko M.V. Byull. Moskov. obshchestva ispytatelei prirody, Otd. biol., 1981, 86(3): 117-124. [Гелюта В.П., Горленко М.В. К систематике и распространению Microsphaera van-bruntiana Ger. в европейской части СССР. Бюлл. Моск. об-ва испытат. природы, Отд. биол., 1981, 86(3): 117-124].

Heluta V.P., Gorlenko M.V. Mikologiya i fitopatologiya, 1984, 18(3): 177-182. [Гелюта В.П., Горленко М.В. Microsphaera palczewskii Jacz. в СССР. Микол. и фитопатол., 1984, 18(3): 177-182].

Heluta V.P., Kovalchuk V.P., Chumak P.Ya. First records of teleomorph of an invasive fungus Erysiphe macleayae (Erysiphales) in Ukraine. Ukr. Bot. J., 2016, 73(3): 268-272.

Heluta V.P., Kravchuk O.O. Ukr. Bot. J., 2015, 72(1): 3945. [Гелюта В.П., Кравчук О.О. Перші знахідки в Україні нового інвазійного гриба Erysiphe macleayae (Erysiphales). Укр. бот. журн., 2015, 72(1): 39-45].

Heluta V., Takamatsu S., Harada M., Voytyuk S. Molecular phylogeny and taxonomy of Eurasian Neoerysiphe species infecting Asteraceae and Geranium. Persoonia, 2010, 24: 81-92. doi:10.3767/003158510X501696.

Heluta V.P., Takamatsu S., Voytyuk S.O., Shiroya Y. Erysiphe kenjiana (Erysiphales), a new invasive fungus in Europe. Mycol. Progr., 2009, 8: 367-375. doi: 10.1007/ s11557-009-0610-8

Heluta V.P., Tykhonenko Yu.Ya., Burdyukova L.I., Dudka I.A. Parazitnye griby stepnoy zony Ukrainy, Kiev: Naukova Dumka, 1987, 279 pр. [Гелюта В.П., Тихоненко Ю.Я., Бурдюкова Л.И., Дудка И.А. Паразитные грибы степной зоны Украины, Киев: Наук. думка, 1987, 279 c.].

Jankovics T. First report of powdery mildew (Oidium sp.) on great celandine (Chelidonium majus). Plant Pathol., 2007, 56: 353-359.

Kokhno N.A., Kaplunenko N.F., Minchenko N.F., Doroshenko A.K., Horb V.K., Orlov M.I., Kurdyuk A.M., Parkhomenko L.I., Tsikalyak H.P., Mamushkina T.S., Hordienko N.M. Derevya i kustarniki, kultiviruemye $v$ Ukrainskoy SSR. Pokrytosemennye, Kiev: Naukova Dumka, 1986, 720 pp. [Кохно Н.А., Каплуненко Н.Ф., Минченко Н.Ф., Дорошенко А.К., Горб В.К., Орлов М.И., Курдюк А.М., Пархоменко Л.И., Цикаляк Г.П., Мамушкина Т.С., Гордиенко Н.М. Деревья и кустарники, культивируемые в Украинской ССР. Покрытосеменные, Киев: Наук. думка, 1986, 720 с.].

Lebeda A., Mieslerová B., Sedlářová M., Pejchal M. Occurrence of anamorphic and teleomorphic stage of Erysiphe palczewskii (syn. Microsphaera palczewskii) on Caragana arborescens in the Czech Republic and Austria and its morphological characterisation. Plant Protect. Sci., 2008, 44: 41-48.

Mosyakin S.L., Fedoronchuk M.M. Vascular plants of Ukraine, Kiev, 1999, xxiii+345 pp.
Mukhina L.N., Seraya L.G., Kashtanova O.A. Lesokhozyaystv. informatsiya, 2015, 2: 57-64. [Мухина Л.Н., Серая Л.Г., Каштанова О.А. Мониторинг энтомофитопатологического состояния древесных растений Главного ботанического сада РАН. Лесохозяйств. информация, 2015, 2: 57-64].

Pastirčáková K., Takamatsu S., Shiroya Y., Pastirčák M. European hornbeam powdery mildew Erysiphe arcuata in Slovakia. J. Phytopathol., 2008, 156: 597-601.

Romaszewska-Sałata J., Sałata B., Mułenko W. O interesuacych przewstawicielach Peronosporales i Erysiphales, zebranych ostatnio w Polsce. Folia Soc. Lublinen., 1986, 28, 1: $11-18$.

Scholler M. Morphologische und chorologische Untersuchungen an Microsphaera palczewskii (Erysiphales). Feddes Rep., 1994, 105(5-6): 377-382.

Seko Y., Bolay A., Kiss L., Heluta V., Grigaliunaite B., Takamatsu S. Molecular evidence in support of recent migration of a powdery mildew fungus on Syringa spp. into Europe from East Asia. Plant Pathol., 2008, 57: 243-250.

Seko Y., Heluta V., Grigaliunaite B., Takamatsu S. Morphological and molecular characterization of two ITS groups of Erysiphe (Erysiphales) occurring on Syringa and Ligustrum (Oleaceae). Mycoscience, 2011, 52(3): 171-182.

Shin H.D. Erysiphaceae of Korea, Suwon (Korea): Nat. Inst. Agricult. Sci. Tech., 2000, 320 pp.

Shukanov A.S., Stefanovich A.I. Vestn. Belorus. Univ., Ser. 2, 1986, 1: 26-30. [Шуканов А.С., Стефанович А.И. Мучнисторосяные грибы деревьев и кустарников Ботанического сада БГУ им. В.И. Ленина и его окрестностей. Вестн. Белорус. ун-та, Сер. 2, 1986, 1: 26-30].

Silvestro D., Michalak I. raxmlGUI: a graphical front-end for RAxML. Organisms Diversity Evol., 2012, 12: 335337. doi: 10.1007/s13127-011-0056-0

Spooner B.M., Roberts P.J. New British records. 191. Microsphaera palczewskii Jaczewski. 192. Hyphodontia spathulata (Schrad.) Parmasto. 193. Psedotrichia minor Munk. 194. Subbaromyces splendens Hesseltine. Orbilia aurantiorubra Boud. Mycologist, 2001, 15(3): 134-135.

Swofford D.L. PAUP* $4.0 b 10$ phylogenetic analysis using parsimony (*and other methods), Sunderland: Sinauer Assoc., 2002.

Takamatsu S., Matsuda S., Grigaliunaite B. Comprehensive phylogenetic analysis of the genus Golovinomyces (Ascomycota: Erysiphales) reveals close evolutionary relationships with its host plants. Mycologia, 2013, 105(5): 1135-1152. doi: 10.3852/13-046.

Tamura K., Stecher G., Peterson D., Filipski A., Kumar S. MEGA6: molecular evolutionary genetics analysis version 6.0. Mol. Biol. Evol., 2013, 30(12): 2725-2729. doi: $10.1093 / \mathrm{molbev} / \mathrm{mst} 197$.

Voytyuk S.O., Heluta V.P., Wasser S.P., Nevo E., Takamatsu S. Biodiversity of the powdery mildew fungi (Erysiphales, Ascomycota) of Israel (Biodiversity of cyanoprocaryotes, algae and fungi of Israel). Ed. Paul A. Volz, Ruggel: A.R.G. Gantner Verlag K.-G., 2009, 290 pp.

Recommended for publication by

Submitted 02.05.2017 V.P. Hayova 
Гелюта В.П. ${ }^{1}$, Такамацу С. ${ }^{2}$, Сіахаан С.А.С. ${ }^{2}$

Erysiphe salmonii (Erysiphales, Ascomycota) - ще один східноазійський борошнисторосяний гриб, занесений до України. Укр. бот. журн., 2017, 74(3): 212-219.

${ }^{1}$ Інститут ботаніки ім. М.Г. Холодного НАН України вул. Терещенківська, 2, Київ 01004, Україна

${ }^{2}$ Університет Міє

1577 Куріма-Мачія, Цу 514-8507, Японія

Повідомляється, що 2015 р. в Україні (Київ) була зареєстрована борошниста роса на двох видах ясеня - Fraxinus excelsior та $F$. pennsylvanica (Oleaceae), яка викликалася грибом, що належав до Erysiphe sect. Uncinula. У peзультаті порівняльного аналізу українських матеріалів 3 описами уже відомих на ясені $E$. fraxinicola i $E$. salmonii та їхніми зразками, зібраними у Східній Азії, гриб було ідентифіковано як E. salmonii. Таке визначення підтверджене результатами молекулярно-філогенетичного аналізу. Це перше повідомлення про реєстрацію даного гриба не тільки в Україні, а й в Європі. Однак при цьому висловлюється припущення, що борошнисторосяний гриб, знайдений на ясені у Білорусі та Росії і наведений як Uncinula fraxini (= E. fraxinicola), міг бути ідентифікований помилково і має належати до E. salmonii. У 2016 р. даний гриб виявлений не тільки в Києві, а й на околиці міста. Його розвиток має ознаки епіфітотії. Отже, не виключено, що E. salmonii належить до інвазійних видів і найближчим часом його слід очікувати в Західній Європі.

Ключові слова: молекулярна філогенія, Uncinula, декоративне насадження, Fraxinus, ясен, Европа
Гелюта В.П. ${ }^{1}$, Такамацу С. ${ }^{2}$, Сиахаан С.А.С. ${ }^{2}$

Erysiphe salmonii (Erysiphales, Ascomycota) - еще один восточноазиатский мучнисторосяной гриб, занесенный в Украину. Укр. бот. журн., 2017, 74(3): 212-219.

${ }^{1}$ Институт ботаники им. Н.Г. Холодного НАН Украины ул. Терещенковская, 2, Киев 01004, Украина

${ }^{2}$ Университет Мие 1577 Курима-Мачия, Цу 514-8507, Япония

Сообщается, что в 2015 г. в Украине (Киев) была зарегистрирована мучнистая роса на двух видах ясеня - Fraxinus excelsior и $F$. pennsylvanica (Oleaceae), которая вызывалась грибом, принадлежащим к Erysiphe sect. Uncinula. В peзультате сравнительного анализа украинских материалов с описаниями уже известных на ясене $E$. fraxinicola и E. salmonii и их образцами, собранными в Восточной Азии, гриб был идентифицирован как E. salmonii. Такое его определение подтверждено результатами молекулярно-филогенетического анализа. Это первое сообщение о регистрации данного гриба не только в Украине, но и в Европе. Однако при этом высказывается предположение, что мучнисторосяной гриб, найденный на ясене в Беларуси и России и приведенный как Uncinula fraxini (= E. fraxinicola), мог быть идентифицирован ошибочно и должен принадлежать к E. salmonii. В 2016 г. данный гриб выявлен не только в Киеве, но и в окрестностях города. Его развитие имеет признаки эпифитотии. Таким образом, не исключено, что E. salmonii принадлежит к инвазионным видам и в ближайшее время его следует ожидать в Западной Европе.

Ключевые слова: молекулярная филогения, Uncinula, декоративное насаждение, Fraxinus, ясень, Европа 